

 \\ ISSN: 0973-4945; CODEN ECJHAO \\ E-Journal of Chemistry
}

Vol. 4, No.1, pp 109-116, January 2007

\section{Determination of Finasteride in Tablets by High Performance Liquid Chromatography}

\author{
K BASAVAIAH* and B C SOMASHEKAR \\ Department of Post Graduate Studies and Research in Chemistry, \\ University of Mysore, Manasagangotri, Mysore-570006, India.
}

Received 1 September 2006; Revised 22 October 2006; Accepted 2 November 2006

\begin{abstract}
A rapid, highly sensitive high performance liquid chromatographic method has been developed for the determination of finasteride(FNS) in bulk drug and in tablets. FNS was eluted from a ODS $\mathrm{C}_{18}$ reversed phase column at laboratory temperature $\left(30 \pm 2^{\circ} \mathrm{C}\right)$ with a mobile phase consisting of methanol and water $(80+20)$ at a flow rate of 1


and each analysis took not more than $10 \mathrm{~min}$. Quantitation was achieved by measurement of peak area without using any internal standard. Calibration graph was linear from 2.0 to $30 \mu \mathrm{g} \mathrm{mL}^{-1}$ with limits of detection (LOD) and quantification (LOQ) being 0.2 and $0.6 \mu \mathrm{g} \mathrm{mL}^{-1}$, respectively. The method was validated according to the current ICH guidelines. Within-day co efficients of variation (CV) ranged from 0.31 to $0.69 \%$ and between-day $\mathrm{CV}$ were in the range $1.2-3.2 \%$. Recovery of FNS from the pharmaceutical dosage forms ranged from $97.89-102.9$ with CV of $1.41-4.13 \%$. The developed method was compared with the official method for FNS determination in its tablet forms.
\end{abstract}

Keywords: Finasteride, determination, high-performance liquid chromatography, pharmaceutical product, quantitation. 


\section{Introduction}

Finasteride (FNS), chemically known as N-(1,1-dimethylethyl) - 3- oxo- $(5 \alpha, 17 \beta)-4$ azaandrost- 1- ene-17- carboxamide (Fig.1) ${ }^{1}$, is an antiandrogen which acts by inhibiting 5alpha reductase, the enzyme that converts testosterone to dihydrotestosterone ${ }^{2}$. It is used in benign prostatic hyperplasia (BPH) in low doses and in prostate cancer in higher doses. Additionally, it is registered in many countries for male pattern-baldness. The therapeutic importance of FNS has necessitated the development of analytical methods for its determination in dosage forms in compliance with good manufacturing standards.



Figure 1. Structure of drug

Numerous methods have been reported for the assay of FNS in pure forms and in its pharmaceuticals preparations. Procedures using UV-spectrophotometry ${ }^{3}$, HPTLC $^{4}$, mid-infrared spectrophotometry ${ }^{5}$ visible spectrophotometry ${ }^{6}$, polarography ${ }^{7}$, have been reported by several workers. The drug is official in Martindale, The Extra Pharmacopeia ${ }^{8}$ and United States Pharmacopoeia ${ }^{9}$ and the latter describes HPLC procedure for assay in pure drug and in tablets.

Many papers have been published on the determination of FNS in biological fluids ${ }^{10}$ particularly in human plasma using high performance liquid chromatograph (HPLC) ${ }^{11-18}$ with different column materials and mobile phase systems. Many HPLC methods have been developed for FNS in pharmaceuticals. An HPLC method established by Ziyang et al ${ }^{19}$ uses a Dikma Discovery ODS column $(4.6 \mathrm{~mm} \times 250 \mathrm{~mm}, 5 \mu \mathrm{m})$ with $\mathrm{H}_{2} \mathrm{O}-\mathrm{MeCN}-\mathrm{THF}$ $(8: 2.5: 2.5)$ as mobile phase and the detection at $210 \mathrm{~nm}$ and the flow rate of $1.0 \mathrm{ml} \mathrm{min}^{-1}$. In a method proposed by Mufeng $e t a l^{20}$ FNS was determined by RP-HPLC at $210 \mathrm{~nm}$ on ODS C18 column with water-acetinitrile-tetrahydrofuran $(8: 2: 5: 1)$ as the mobile phase. A method developed for simultaneous determination of finasteride and its degradation product by Segall $e t$ $a l^{21}$ was carried out using a C18 column and methanol:water (70:30) as the mobile phase. A RPHPLC method for FNS in tablets has been reported by Xin-yuan $e t a l^{22}$ and was carried out on an ODS-C18 $(250 \mathrm{~mm} \times 4.6 \mathrm{~mm}, 5 \mu \mathrm{m})$ column and $\mathrm{MeOH}-\mathrm{H}_{2} \mathrm{O}(8: 2)$ as the mobile phase and a detection wavelength of $220 \mathrm{~nm}$. Hulya et al., ${ }^{23}$ reported a method in which the analysis was performed using Nova Pak C18 column at $60^{\circ} \mathrm{C}$ by using a mobile phase water/acetonitrile/tetrahydrofuran $(80 / 10 / 10, \mathrm{v} / \mathrm{v})$ and flow rate of $2 \mathrm{~mL} \mathrm{~min}^{-1}$ at $210 \mathrm{~nm}$. Li et $a l^{24}$ have reported an HPLC method for the assay of FNS in capsules on a C18 column $(250 \mathrm{~mm}$ $\times 4.6 \mathrm{~mm} 5 \mu \mathrm{m}$ ) with a mobile phase of $\mathrm{MeOH}-\mathrm{H}_{2} \mathrm{O}$ and detection at $220 \mathrm{~nm}$. A method reported by Rongfeng et $\mathrm{al}^{25}$ uses BDS column $(250 \mathrm{~mm} \times 5 \mathrm{~mm}, 5 \mu \mathrm{m})$ with THF-MeOH- $\mathrm{H}_{2} \mathrm{O}$ (30:5:65, $\mathrm{pH} 3.0$ ) as mobile phase and detection at $240 \mathrm{~nm}$. A reversed-phase HPLC was reported by Syed and Amshumali ${ }^{26}$ in which the separation and determination were performed on a Shimpak C8 column and UV-detection $(210 \mathrm{~nm})$ at ambient temperature $\left(25^{\circ}\right)$ with a mobile phase of MeCN$\mathrm{H}_{2} \mathrm{O}$ (95:5) and flow rate of $0.7 \mathrm{~mL} \mathrm{~min}^{-1}$. 
This paper describes the development and validation of an HPLC method without incorporating the use of internal standard for the determination of FNS in pharmaceutical formulations. The method has been demonstrated to be both accurate and precise in addition to being more sensitive than many reported HPLC procedures (Table 1).

Table 1. Comparision of existing HPLC methods with proposed methods

\begin{tabular}{|c|c|c|c|c|c|}
\hline $\begin{array}{l}\text { S } \\
\text { No. }\end{array}$ & $\begin{array}{l}\text { Chromatographic } \\
\text { conditions }\end{array}$ & $\begin{array}{l}\lambda_{\max } \\
\mathrm{nm}\end{array}$ & $\begin{array}{l}\text { Linear } \\
\text { range } \\
\mu g \mathrm{~mL}^{-1}\end{array}$ & Remarks & Ref \\
\hline 1. & $\begin{array}{l}\text { Dikma Discovery } \\
\text { ODS( } 4.6 \mathrm{~mm} \times 250 \mathrm{~mm} \text {, } \\
5 \mu \mathrm{m}) \text { with } \mathrm{H}_{2} \mathrm{O}-\mathrm{MeCN} \\
\text {-THF }(8: 2.5: 2.5) \text { as mobile } \\
\text { phase at } 1 \mathrm{~mL} \mathrm{~min}^{-1} .\end{array}$ & 210 & $0.604-6.04$ & & 19 \\
\hline 2. & $\begin{array}{l}\text { ODS C18 column with water } \\
\text { acetonitrile-THF( } 8: 2.5: 1) \text { as } \\
\text { mobile phase }\end{array}$ & 210 & $15-150$ & Less sensitive & 20 \\
\hline 3. & $\begin{array}{l}\text { C18 column; methanol: } \\
\text { water }(70: 30) \text { at } 1 \mathrm{~mL} \mathrm{~min}^{-1} \text {. }\end{array}$ & 210 & $50-800$ & Least sensitive & 21 \\
\hline 4. & $\begin{array}{l}\text { ODS-C18(250 } \times 4.6 \mathrm{~mm} \text {, } \\
5 \mu \mathrm{m}) \text { Column and } \mathrm{MeOH}- \\
\mathrm{H}_{2} \mathrm{O}(8: 2) \text { as the mobile } \\
\text { phase }\end{array}$ & 220 & $2-20$ & & 22 \\
\hline 5. & $\begin{array}{l}\text { Nova Pak C18 column at } \\
60^{\circ} \mathrm{C} \text { by using water: } \\
\text { acetonitrile:THF } \\
(80: 10: 10, \mathrm{vol} / \mathrm{vol}) \text { at } 2 \mathrm{~mL} \\
\min ^{-1}\end{array}$ & 210 & & & 23 \\
\hline 6. & $\begin{array}{l}\mathrm{C} 18(250 \mathrm{~mm} \times 4.6 \mathrm{~mm} \\
5 \mu \mathrm{m}) ; \mathrm{MeOH}-\mathrm{H}_{2} \mathrm{O}\end{array}$ & 220 & $0.06-0.14$ & Narrow range & 24 \\
\hline 7. & $\begin{array}{l}\text { BDS column }(250 \mathrm{~mm} \times 5 \\
\mathrm{mm}, 5 \mu \mathrm{m}) \text { with THF- } \\
\mathrm{MeOH}-\mathrm{H}_{2} \mathrm{O} \\
\text { (30:5:65, pH 3.0) as mobile } \\
\text { phase }\end{array}$ & 240 & & & 25 \\
\hline 8. & 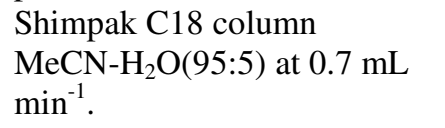 & 210 & $20-600$ & Less sensitive & 26 \\
\hline 9. & $\begin{array}{l}\text { Reversed phase ODS }\left(\mathrm{C}_{18}\right. \\
250 \times 4.6 \mathrm{~mm}) \text { column } \\
\text { using a mobile phase } \\
\text { methanol and water }(80: 20) \\
\text { at } 1.0 \mathrm{~mL} \mathrm{~min}^{-1} .\end{array}$ & 225 & $2-30$ & $\begin{array}{l}\text { Sensitive, wide } \\
\text { linear dynamic } \\
\text { range of } \\
\text { applicability, } \\
\text { uses no internal } \\
\text { standard }\end{array}$ & $\begin{array}{l}\text { Present } \\
\text { method }\end{array}$ \\
\hline
\end{tabular}




\section{Experimental}

\section{Apparatus}

An HPLC Shimadzu 1100 series, Schimadzu Technologies, Japan, equipped with an inbuilt solvent degasser, quaternary pump, photodiode array detector with variable injector and an auto sampler, and a reverse phase. ODS $\mathrm{C}_{18}(250 \times 4.6 \mathrm{~mm}$ i.d $)$ column.

\section{Reagents and materials}

Distilled water filtered through $0.45 \mu$ filter was used to prepare solutions.

\section{Mobile phase}

The solution was prepared by mixing HPLC grade methanol (Rankem, India) and water in the ratio 80:20.

\section{Standard drug solution}

A stock standard solution containing $500 \mu \mathrm{g} \mathrm{mL}^{-1}$ FNS were prepared by dissolving $50.0 \mathrm{mg}$ of pure drug in mobile phase and diluting to the mark in a $100 \mathrm{~mL}$ calibrated flask. It was then diluted to $100 \mu \mathrm{g} \mathrm{mL}^{-1} \mathrm{FNS}$ with the mobile phase.

\section{Procedure}

\section{Chromatographic conditions}

The chromatographic separation was achieved at ambient temperature on a reversed phase ODS $\mathrm{C}_{18}(250 \times 4.6 \mathrm{~mm})$ column using a mobile phase methanol and water in the ratio 80:20 at flow rate $1.0 \mathrm{~mL} \mathrm{~min}^{-1}$. The detector wavelength was set at $225 \mathrm{~nm}$ with a sensitivity of 0.2 a.u.f.s.

\section{Preparation of calibration graph}

Working standard solutions containing 2-30 $\mu \mathrm{g} \mathrm{mL}^{-1}$ FNS were prepared by appropriate dilution of the working standard solution with the mobile phase. Twenty $\mu \mathrm{L}$ aliquot of each solution was injected automatically into the column in duplicate and the chromatograms were recorded. Calibration graph was constructed by plotting the mean peak area versus concentration of FNS. The concentration of the unknown was read from the calibration graph or calculated with the help of regression equation derived from the peak area-concentration data.

\section{Assay procedure for formulations}

An amount of tablet powder equivalent to $50 \mathrm{mg}$ of FNS was accurately transferred into a $100 \mathrm{~mL}$ calibrated flask, $60 \mathrm{~mL}$ mobile phase added and shaken for $20 \mathrm{~min}$. The mixture was diluted to the mark with the mobile phase and mixed well. A small portion of this $(\sim 10$ $\mathrm{mL}$ ) was withdrawn and filtered through a $0.2 \mu \mathrm{m}$ filter to ensure the absence of particulate matter. The filtered solution was appropriately diluted to get a convenient working concentration and $20 \mu \mathrm{L}$ aliquot was then injected to get the chromatogram.

\section{Results and Discussion}

\section{Method Development}

FNS was determined by HPLC injecting the solution on to ODS $\mathrm{C}_{18}(250 \times 4.6 \mathrm{~mm})$ column with UV detector set at $225 \mathrm{~nm}$. No internal standard was used. The composition of the mobile phase and its flow rate were varied to optimize the chromatographic conditions. A mobile phase consisting of methanol and water in the ratio 80:20 was selected after several preliminary experiments. At a flow rate of $1.0 \mathrm{~mL} \mathrm{~min}^{-1}$, the retention time for FNS was $6.10 \mathrm{~min}$. Under the described experimental conditions the analyte peak was well defined and free from tailing (Fig. 2). 


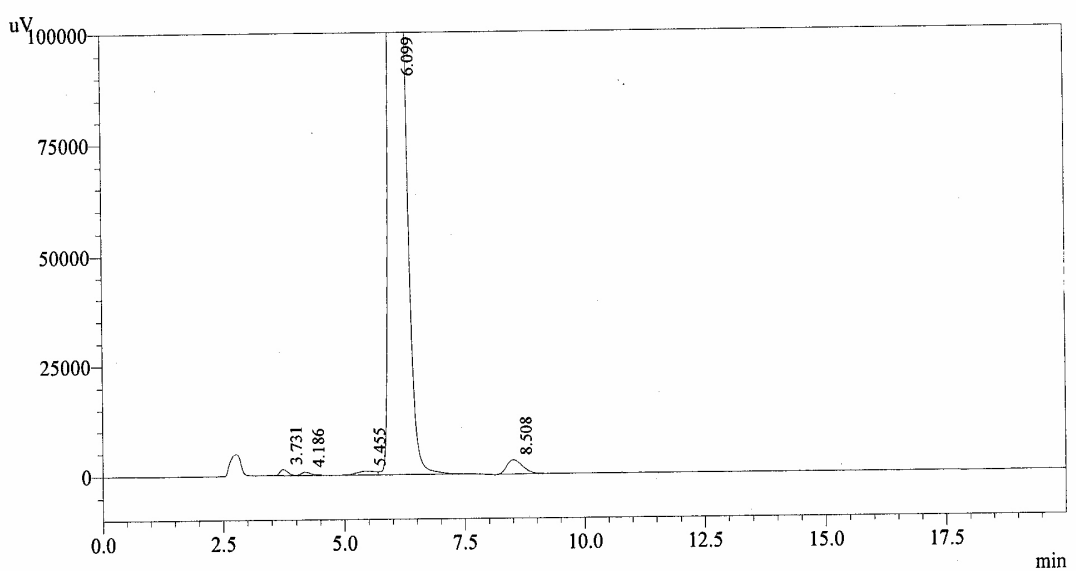

Figure 2. Typical chromatogram

\section{Method validation}

The concentration of the unknown was determined by measuring the peak area. A plot of mean peak area versus concentration gave a linear relationship $(r=0.9992)$ over the concentration range 2-30 $\mu \mathrm{g} \mathrm{mL}^{-1}$ (Fig. 3). Using the method of least squares, the linear regression equation obtained was

$$
\mathrm{Y}=160885.400+224285.96 \mathrm{X}
$$

where $\mathrm{Y}$ is the mean peak area and $\mathrm{X}$ concentration in $\mu \mathrm{g} \mathrm{mL}^{-1}$. The LOD was calculated to be $0.2 \mu \mathrm{g} \mathrm{mL}^{-1}$ and the LOQ was calculated to be $0.6 \mu \mathrm{g} \mathrm{mL}^{-1}$.

\section{Precision and accuracy of the method}

The within-day precision of the method was determined by replicate analyses of the standard solution containing FNS at three different concentration levels and the results are presented in Table 2. The relative standard deviation (RSD) which is a measure of precision was evaluated for both retention time and peak area. The inter-day precision was established by performing analysis over a 5 days period with solutions prepared freshly each day. The RSD value were not more than $2 \%$. In order to demonstrate the accuracy of the proposed methods, seven replicate analyses were performed on solutions containing FNS at three different levels. The results obtained are compiled in Table 2 . and the accuracy expressed as percent relative error was found satisfactory. $(<1 \%)$.

Table 2. Evaluation of accuracy and precision

\begin{tabular}{clllllll}
\hline $\begin{array}{l}\text { FNS } \\
\text { taken } \\
\mu \mathrm{g} \mathrm{mL}^{-1}\end{array}$ & $\begin{array}{c}\text { FNS } \\
\text { found } \psi \\
\mu \mathrm{g} \mathrm{mL}\end{array}$ & $\begin{array}{l}\text { Range, } \\
\mu \mathrm{g} \mathrm{mL}^{-1}\end{array}$ & $\begin{array}{l}\mathrm{RE} \\
\%\end{array}$ & $\begin{array}{l}\text { RSD* } \\
\%\end{array}$ & $\begin{array}{l}\mathrm{ROE}^{*} \\
\%\end{array}$ & RSD** & $\begin{array}{c}\mathrm{ROE}^{* *} \\
\%\end{array}$ \\
\hline 5 & 4.95 & 0.18 & 1.00 & 0.65 & \pm 0.65 & 0.34 & \pm 0.34 \\
15 & 14.90 & 0.22 & 0.67 & 0.39 & \pm 0.39 & 0.24 & \pm 0.24 \\
25 & 24.88 & 0.25 & 0.48 & 0.31 & \pm 0.31 & 0.52 & \pm 0.52 \\
\hline
\end{tabular}

$\psi$ Mean value of seven determination;* Based on peak area;

RE - Relative error; RSD - Relative standard deviation;

ROE - Range of error at $95 \%$ confidence level.

* Based on peak area; ** Based on retention time. 




\section{Application}

Figure 3. Linearity curve

Commercially available tablets containing FNS were analysed by the described HPLC method. The results obtained are summarized in Table 3. As can be seen, the results are in agreement with the labeled amounts. For comparison, a conventional UV-absorption method $^{13}$ which consisted of the measurement of the absorbance of the drug solution in methanol at $206 \mathrm{~nm}$, was used to analyse the same batch tablets. The results, compiled in Table 3 were statistically compared by Student's t-test and F-test. As shown, the calculated $\mathrm{t}$ - and F-values were less than the tabulated values inferring that the proposed methods have the same accuracy and precision as that of the reference method at the $95 \%$ confidence level. The accuracy and reliability of the methods were further established by performing recovery experiments. The pre-analysed tablet/powder was spiked with pure FNS at three different levels and the total was found by the proposed methods. Each experiment was repeated three times. The recoveries of the added pure drug were in the range 97.89-102.9\% (Table 4) indicating that co-formulated substances such as talc, starch, gumacacia, lactose, magnesium stearate, sodium alginate, calcium gluconate, and calcium dihydrogenorthophosphate did not interfere in the determination.

Table 3. Results of analysis of formulations containing finasteride

\begin{tabular}{cccl}
\hline $\begin{array}{l}\text { Tablet and } \\
\text { brand name* }^{*} \begin{array}{l}\text { Nominal amount } \\
\text { g/tablet }\end{array}\end{array}$ & \multicolumn{2}{l}{ Found**(\% of nominal amount \pm SD) } \\
\cline { 2 - 4 } Fincar $^{\mathrm{a}}$ & 5 & Reference method & HPLC method \\
& & $99.36 \pm 0.74$ & $\begin{array}{l}98.13 \pm 1.42 \\
\mathrm{t}=1.80\end{array}$ \\
& 5 & & $\mathrm{~F}=3.68$ \\
Fistide $^{\mathrm{b}}$ & 5 & $100.28 \pm 0.91$ & $\begin{array}{l}102.1 \pm 1.28 \\
\mathrm{t}=2.63\end{array}$ \\
& & & $\mathrm{~F}=1.98$ \\
\hline
\end{tabular}

* Marketed by: a. Cipla. Ltd., India ; b. Samarth. Pharm. Ltd.

** Mean value of five determinations;

Tabulated t-value at $95 \%$ confidence level in 2.77 ;

Tabulated F-value at $95 \%$ confidence level in 6.39 . 
Table 4. Results of recovery experiments

\begin{tabular}{ccccc}
\hline & \multicolumn{4}{c}{ HPLC method } \\
\cline { 2 - 5 } Tablet studied & $\begin{array}{c}\text { FNS in tablet } \\
\mu \mathrm{g} \mathrm{mL}^{-1}\end{array}$ & $\begin{array}{c}\text { Pure drug added, } \\
\mu \mathrm{g} \mathrm{mL}^{-1}\end{array}$ & $\begin{array}{c}\text { Total found } \\
\mu \mathrm{g} \mathrm{mL} \mathrm{m}^{-1}\end{array}$ & $\begin{array}{c}\text { Recovery* of } \\
\text { pure drug added, } \\
\%\end{array}$ \\
\hline \multirow{2}{*}{ Fistide } & 10.2 & 5.0 & 15.35 & 102.9 \\
$(5 \mathrm{mg})$ & 10.2 & 10.0 & 19.99 & 97.89 \\
& 10.2 & 15.0 & 25.43 & 101.5 \\
\hline
\end{tabular}

\section{Conclusion}

* Mean value of three determinations.

The proposed HPLC method is rapid, superior to many reported previously in terms sensitivity, linear range of response and analysis time. A single chromatographic run took less than $10 \mathrm{~min}$. Besides being highly sensitive, the procedure is intended to determine FNS in single component formulations, it can conveniently be applied for combined dosage forms, since the method is specific for finasteride under the described chromatographic conditions. and is free from the use of internal standard for quantitation. The results obtained indicate that the method described is capable of good accuracy and precision. The method can be used to monitor the content uniformity of tablets and injectables, and purity of finasteride raw material.

\section{References}

1. The Merck Index, $12^{\text {th }}$ Edn., Merck and Co. Inc, White House Station. N J, 1994, p 691.

2. Current Index of Medical Specialities (CIMS), Updated Prescriber's Hand Book, CMPMedia India Pvt. Ltd., Bangalore, India. July-October 2005, p 288.

3. Ilango K, Valentina P and Lakshmi K S, Indian Drugs, 2003, 40, 122.

4. Meyyanathan S N, Ramasarma G V S and Suresh B, J. Planar Chromatogr-Mod. TLC., 2001, 14, 188.

5. Ryan J A, Compton S V, Brooks M A and Compton D A C, J. Pharm. Biomed. Anal., 1991, 9, 303.

6. Ilango K, Valentina P and Lakshmi K S, Indian J. Pharm. Sci., 2002, 64, 174.

7. Amer S.M, Farmaco, 2003, 58, 159.

8. Martindale, The Extrapharmacopoeia, $30^{\text {th }}$ Edn; The pharmaceutical Press London. 1994 p 691.

9. The United States of Pharmacopeia. United States Pharamcopoeial Convention Inc., Rockville. 2005, 29, 907.

10. Carlucci G and Mazzeo P, J. Chromatogr:-B: Biomed. Appl., 1997, 693, 245.

11. Matuszewski B K, Constanzer M L and Chavez-Eng C.M, Anal. Chem., 1998, 70, 882 .

12. Takano T, and Hata S, J. Chromatogr. B: Biomed. Appl., 1996, 676, 141.

13. Constanzer M L, Chavez C M, and Matuszewski B K, J. Chromatogr. B: Biomed. Appl., 1994, 658, 281.

14. Yuquin, Yang Y and Huichen L, Yaowu Fenxi Zazhi, 2005, 25, 30. 
15. Yuquing X and Yanyan L, Zhongguo Yaoke Daxue Xuebao, 2004, 35, 187.

16. Zhiyong C, Xiaoyan Z, and Yifan Z, Dafang, Zhongguo Linchuang Yaolixue Zazhi, 2003, 19, 196.

17. Xiangyang L, Li D and Limin L, Yaохие Xuebao, 2003, 38, 445.

18. Ptacek P, Macek J and Klima J, J. Chromatogr, B: Biomed. Sci. Appl., 2000, 738, 305.

19. Xiangyang L, Yifeng C, Wansheng C, Bin Z and Dongliang Z, Yaowu Fenxi Zazhi. 2003, 23, 46.

20. Mufeng X, Zhongguo Yiyao Gongye Zazhi, 2002, 33, 341.

21. Segalli A I, Vitale M F, Perez V L, Palacious M L, and Pizzorno M T, J. liq. Chromatogr and Rel. Technol., 2002, 25, 3167.

22. Xin-yuan L, and Yu-xin S, Hebei Gongye Daxue Xuebao, 2001, 30, 66.

23. Hulya D, Aysen C and Serap S, Anal. Chim. Acta. 2006, 557, 252.

24. Li Z, Luosheng L, and Fingli L, Yaowu Fenxi Zazhi. 2002, 22, 456.

25. Rongfeng H, Zhiying F, Jian W and Song S, Zhongguo Yiyuan Yaoxue Zazhi 2002, 25, 287.

26. Syed A. A, and Amshumali M. K, J. Pharm. Biomed. Anal., 2001, 25, 1015. 


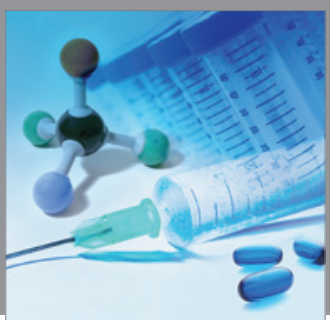

International Journal of

Medicinal Chemistry

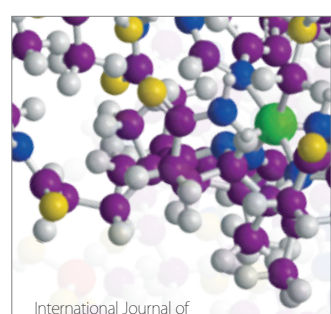

Carbohydrate Chemistry

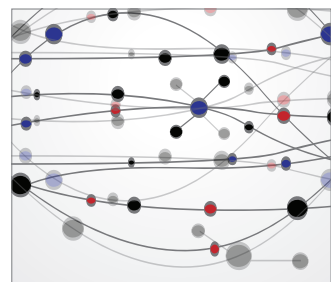

The Scientific World Journal
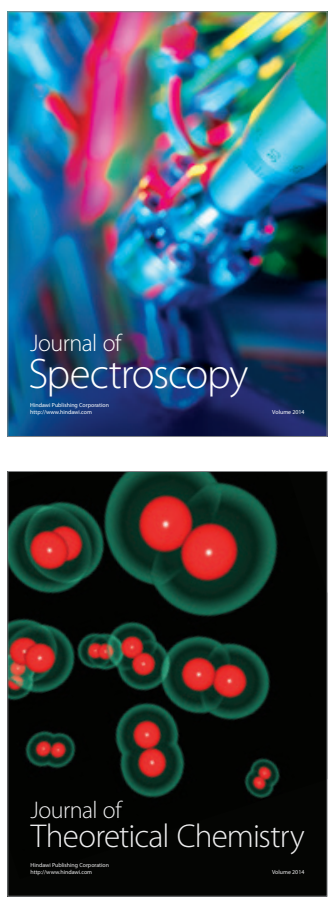
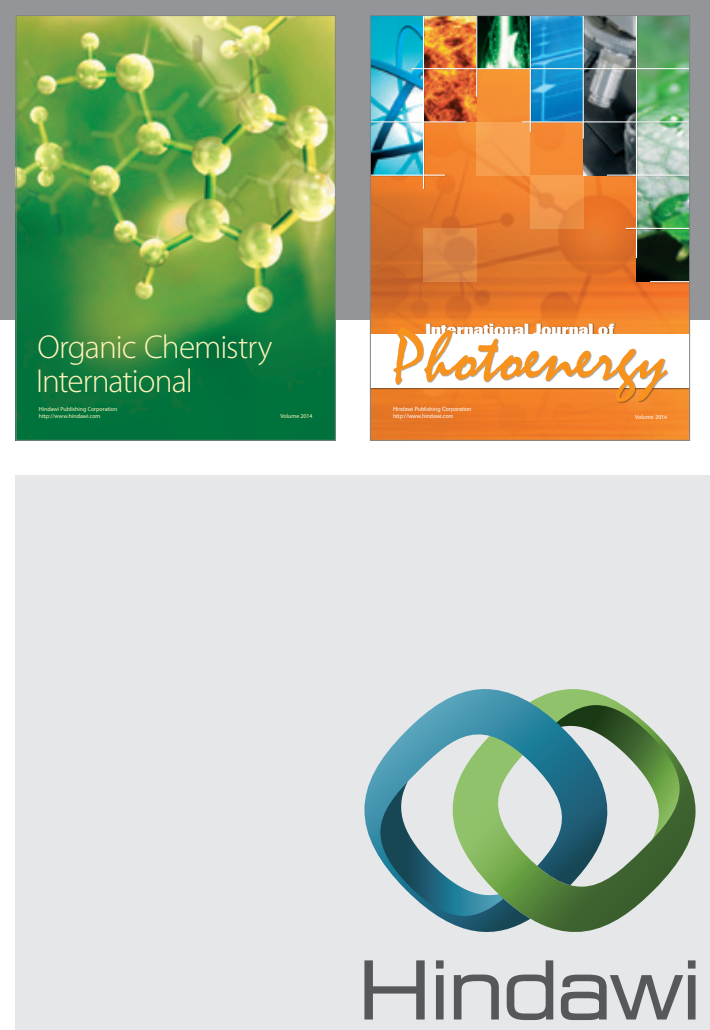

Submit your manuscripts at

http://www.hindawi.com



Journal of

Applied Chemistry
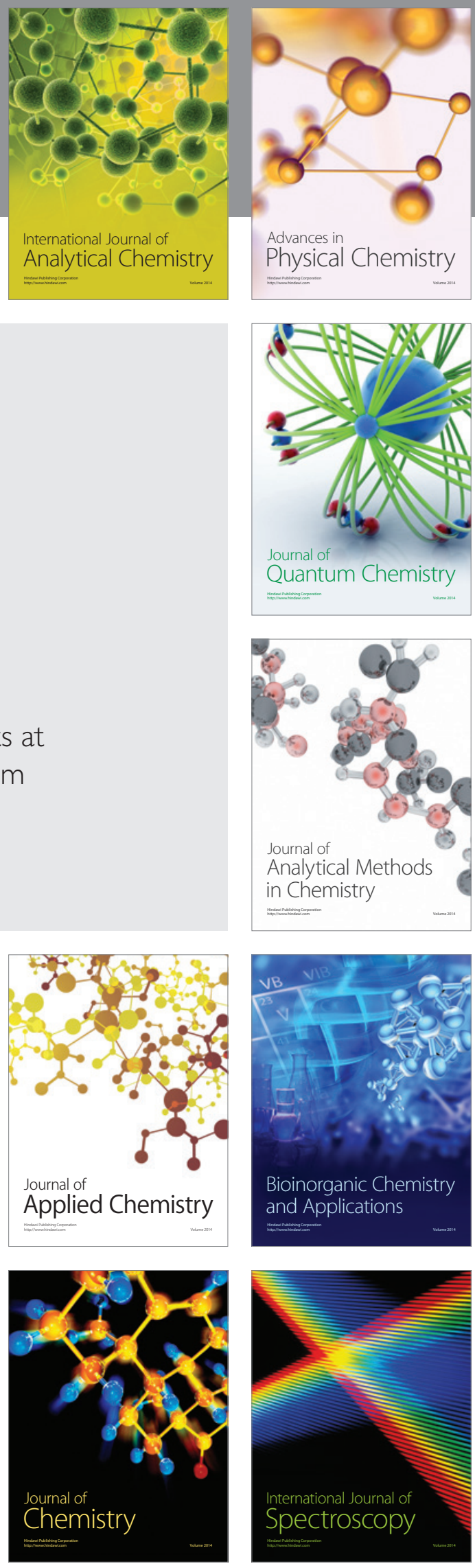